Article

\title{
In Vitro Antimicrobial Activity of Plant-Derived Diterpenes against Bovine Mastitis Bacteria
}

Ariana P. Fonseca ${ }^{1}$, Fernanda T. Estrela ${ }^{1}$, Thaís S. Moraes ${ }^{1}$, Luiza J. Carneiro ${ }^{1}$, Jairo K. Bastos ${ }^{2}$, Raquel A. dos Santos ${ }^{1}$, Sérgio R. Ambrósio ${ }^{1}$, Carlos H. G. Martins ${ }^{1, *}$ and Rodrigo C. S. Veneziani ${ }^{1, *}$

1 Nucleus of Research in Sciences and Technology, University of Franca, Armando Salles de Oliveira Road, 201, Franca 1404-600, Brazil

2 Faculty of Pharmaceutical Sciences of Ribeirão Preto, Laboratory of Pharmacognosy, University of São Paulo, Café Avenue, Ribeirão Preto 14040-903, Brazil

* Authors to whom correspondence should be addressed; E-Mails: martinsc@unifran.br (C.H.G.M.); rcsvenez@unifran.br (R.C.S.V.); Tel./Fax: +55-163711-8871 (C.H.G.M. \& R.C.S.V.).

Received: 27 May 2013; in revised form: 20 June 2013 / Accepted: 21 June 2013 /

Published: 4 July 2013

\begin{abstract}
We evaluated the antibacterial activity of three diterpenes isolated from natural sources against a panel of microorganisms responsible for bovine mastitis. ent-Copalic acid (CA) was the most active metabolite, with promising MIC values (from 1.56 to $6.25 \mu \mathrm{g} \mathrm{mL}^{-1}$ ) against Staphylococcus aureus (ATCC and clinical isolate), Staphylococcus epidermidis, Streptococcus agalactiae, and Streptococcus dysgalactiae. We conducted time-kill assays of CA against $S$. aureus, a commensal organism considered to be a ubiquitous etiological agent of bovine mastitis in dairy farms worldwide. In the first $12 \mathrm{~h}$, CA only inhibited the growth of the inoculums (bacteriostatic effect), but its bactericidal effect was clearly noted thereafter (between 12 and $24 \mathrm{~h}$ ). In conclusion, CA should be considered for the control of several Gram-positive bacteria related to bovine mastitis.
\end{abstract}

Keywords: diterpenes; bovine mastitis; antibacterial; ent-copalic acid

\section{Introduction}

Bovine mastitis is an inflammatory condition that affects the mammary glands of cows. It has a significant impact on animal production, animal welfare, and milk quality [1]. Several Gram-positive and Gram-negative bacteria such as Staphylococcus aureus, Escherichia coli, Staphylococcus epidermidis, 
Streptococcus agalactiae, and Streptococcus dysgalactiae are responsible for this pathology, considered one of the main causes of economic losses in the dairy industry [2,3]. The successful control of this condition generally relies on treatment with antibiotics [1] but this practice contributes to the widespread use of these medications in dairy farms, culminating in antibiotic-resistant bacterial strains $[2,3]$. Therefore, it is necessary to discover novel and safe compounds for the control of this disease.

Natural products are a rich and promising source for the discovery of new biologically active compounds [4]. Among plant metabolites, diterpenes display a wide spectrum of biological activities, including antibacterial action [5-8]. Besides, a search of the scientific literature using PubMed and SciFinder databases reveals that several classes of diterpenoids are considered potential sources of antimicrobial agents [9-14].

In recent years, our research group has investigated the antibacterial activity of naturally occurring diterpenes against bacterial strains responsible for human pathologies like caries, periodontitis, pneumonia, and nosocomial infections, among others. We observed that manool (MO), ent-kaurenoic acid (KA), and ent-copalic acid (CA) were the most promising compounds for most of the tested bacteria [15-18].

Considering the growing need for new antibacterial agents that can be used to control and treat bovine mastitis and as part of our ongoing efforts to explore the antibacterial properties of diterpenes, here we investigate the antimicrobial activity of $\mathrm{MO}, \mathrm{KA}$, and $\mathrm{CA}$ against a representative panel of bacteria responsible for this pathology.

\section{Results and Discussion}

The isolation procedures described in the Experimental section (3.1. Compound Isolation and Identification) furnished the three diterpenes selected for this study (Figure 1). The compounds were identified by ${ }^{1} \mathrm{H}$ and ${ }^{13} \mathrm{C}-\mathrm{NMR}$, and by comparison with literature data as $\mathrm{MO}$ [19,20]; KA [21] and CA [22]. The NMR spectra also indicated that the purity of the isolated compounds lay between 95 and $98 \%$.

Figure 1. Chemical structures of the isolated diterpenes: manool (MO), ent-kaurenoic acid (KA), and ent-copalic acid (CA).

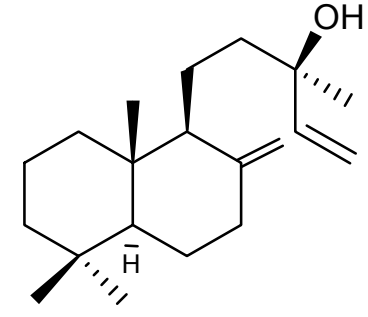

$\mathrm{MO}$

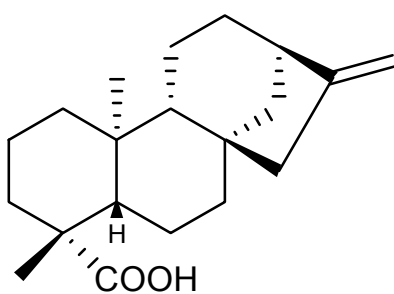

$\mathrm{KA}$

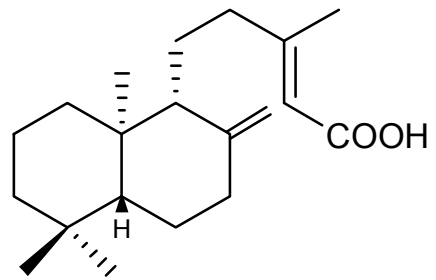

CA

The antimicrobial effects of MO, KA, and CA were evaluated against a panel of ATCC and clinically isolated bacteria associated with bovine mastitis. Table 1 lists the MIC values obtained for the metabolites. 
Table 1. In vitro antibacterial activity (MIC) of manool (MO), ent-kaurenoic acid (KA), and ent-copalic acid (CA).

\begin{tabular}{lllll}
\hline \multirow{2}{*}{ Bacteria } & \multicolumn{3}{c}{ MIC in $\boldsymbol{\mu g} \mathbf{~ m L}^{-\mathbf{1}} \mathbf{( M I C}$ in $\left.\boldsymbol{\mu M}\right)$} \\
\cline { 2 - 5 } & Positive control $^{\mathbf{1}}$ & MO & KA & CA $^{\mathbf{2}}$ \\
\hline S. aureus (ATCC 6538) & $0.05(0.05)$ & $*$ & $*$ & $6.25(20.54)$ \\
S. aureus (clinical isolate) & $>5.89(>6.48)$ & $200.00(689.03)$ & $*$ & $6.25(20.54)$ \\
E. coli (ATCC 14948) & $>1.50(>1.65)$ & $*$ & $*$ & $*$ \\
E. coli (clinical isolate) & $>2.95(>3.25)$ & $*$ & $*$ & $*$ \\
S. epidermidis (ATCC 12228) & $0.05(0.05)$ & $100.00(344.51)$ & $25.00(82.78)$ & $6.25(20.54)$ \\
S. agalactiae (ATCC 12386) & $0.05(0.05)$ & $6.25(21.53)$ & $3.12(10.33)$ & $1.56(5.13)$ \\
S. dysgalactiae (ATCC 12238) & $0.05(0.05)$ & $6.25(21.53)$ & $3.12(10.33)$ & $1.56(5.13)$ \\
\hline
\end{tabular}

* MIC values higher than $400.00 \mu \mathrm{g} \mathrm{mL}^{-1} ;{ }^{1}$ Penicillin was used as positive control. The only exception was

E. coli, for which gentamicin was utilized; ${ }^{2}$ MIC and MBC values for CA were the same for all the tested microorganisms.

Some authors have proposed criteria based on MIC values for the determination of the antimicrobial potential of compounds isolated from natural sources $[23,24]$. These authors suggest that MIC values higher than $100.0 \mu \mathrm{g} \mathrm{mL}^{-1}$ for pure metabolites are evidence of poor activity, while isolated compounds that inhibit the growth of microorganisms at concentrations below $10.0 \mu \mathrm{g} \mathrm{mL}^{-1}$ may be considered promising leads in the search for new anti-infective agents. Bearing these criteria in mind, analysis of the results presented in Table 1 showed that MO, KA, and CA were effective against $S$. agalactiae and S. dysgalactiae. CA was the most active compound, with promising MIC values for most of the investigated bacteria. None of the tested compounds was active against the tested Gram-negative bacterium (E. coli).

$\mathrm{CA}$ at $6.25 \mu \mathrm{g} \mathrm{mL} \mathrm{m}^{-1}$ completely inhibited this microorganism, suggesting that this diterpene is effective against different strains of this species. Moreover, CA was not cytotoxic to the human fibroblast cell line at concentrations up to $62.5 \mu \mathrm{M}$. All these results confirm the role of CA as an important and selective metabolite that should be considered for the control of $S$. aureus.

Gibbons has pointed out that diterpenes are one of the largest groups of plant-derived compounds with potential activity against $S$. aureus, a commensal organism that is considered to be a ubiquitous etiological agent of bovine mastitis in dairy farms worldwide $[25,26]$. Our findings reinforce the role of this class of metabolites against the main pathogen involved in this disease. However, despite the importance of diterpenes as a source for the discovery of new lead anti-infection compounds, reports on the antimicrobial activity of this class of natural products against pathogens responsible for bovine mastitis are scarce. This is the first time that isolated diterpenes have been tested against a panel of microorganisms associated with this infection. Therefore, the present study is important in the search for novel compounds that can be applied for the control of a disease with significant impact on animal production, animal welfare, and milk quality.

Because CA was active against $S$. aureus, one of the etiological agents of bovine mastitis, we decided to investigate other aspects of this antimicrobial activity. Hence, we conducted a time-kill curve set of experiments, to determine how long it is necessary for CA to completely eliminate this pathogen. Figure 2 depicts the obtained time-kill curves. 
Figure 2. Time-kill curves for CA against S. aureus.

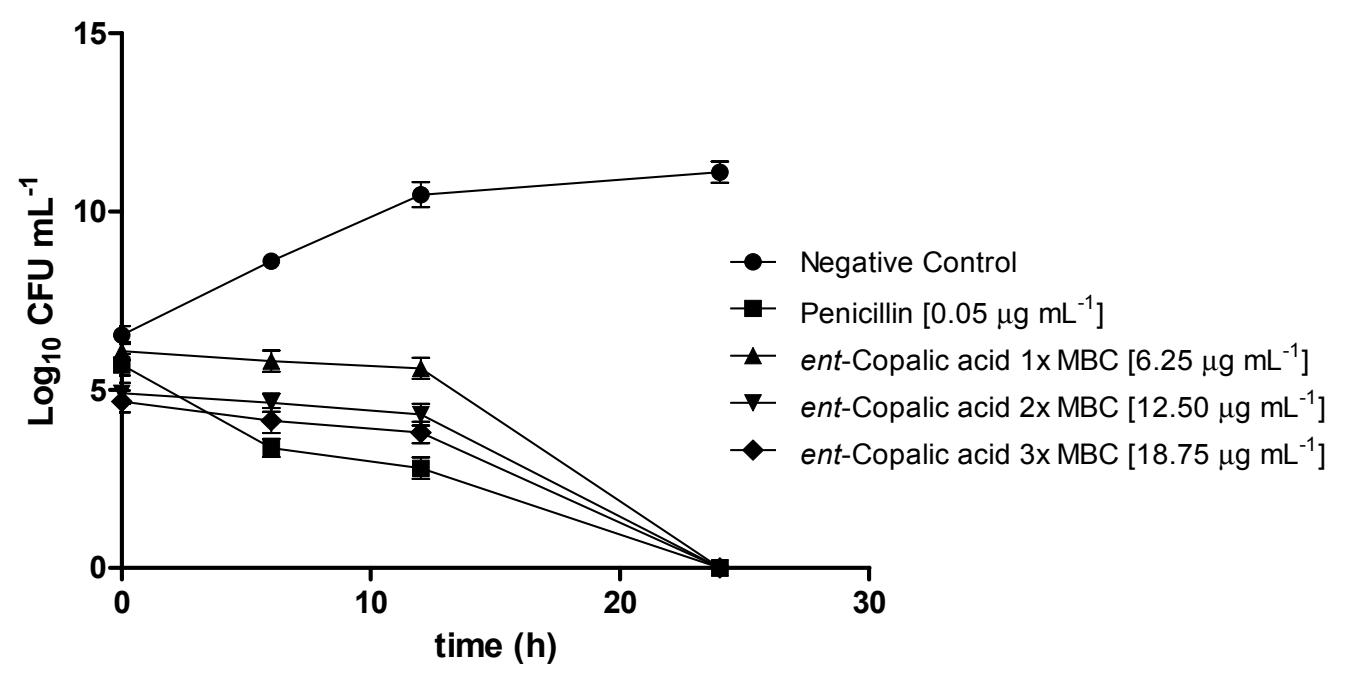

At its $\mathrm{MBC}\left(6.25 \mu \mathrm{g} \mathrm{mL} \mathrm{m}^{-1}\right), \mathrm{CA}$ is able to completely kill $S$. aureus after only $24 \mathrm{~h}$ of incubation. In the first $12 \mathrm{~h}, \mathrm{CA}$ only inhibits the growth of the inoculum, indicating that this metabolite displays a bacteriostatic effect during this period, with its bactericidal effect being clearly noted thereafter (between 12 and $24 \mathrm{~h}$ ). The periods of time investigated for each concentration were not statistically different, showing the lack of dose-dependent responses for this compound in the assayed conditions.

\section{Experimental}

\subsection{Compound Isolation and Identification}

KA and CA were isolated and identified from certified dried leaves of Mikania hirsutissima (purchased from Nutri Comércio de Ervas LTDA, São Paulo, SP, Brazil) and from authentic oleoresin of Copaifera langsdorffii (kindly provided by the Brazilian Company Apis-Flora Comercial e Industrial, Ribeirão Preto, SP, Brazil), respectively, after application of several chromatographic techniques and according to previously described methodologies [16-18]. To obtain MO, certified Salvia officinalis dried leaves $(1.0 \mathrm{Kg})$ were purchased from Nutri Comércio de Ervas LTDA, pulverized, and exhaustively extracted for $48 \mathrm{~h}$ at room temperature with dichloromethane (5 L), to give $45.5 \mathrm{~g}$ of the crude extract, which was suspended in $300 \mathrm{~mL}$ methanol/ $\mathrm{H}_{2} \mathrm{O}(9: 1)$ and filtered. The soluble fraction was partitioned using $n$-hexane $(300 \mathrm{~mL}$, three times), to yield $10.6 \mathrm{~g}$ of hexane-soluble fraction after solvent evaporation under reduced pressure. This fraction was submitted to several chromatographic procedures (vacuum chromatography - VC, Thin layer chromatographyTLC, and High Pressure Liquid Chromatography-HPLC), to afford $200 \mathrm{mg}$ of MO after ${ }^{1} \mathrm{H}-$ and ${ }^{13} \mathrm{C}-\mathrm{NMR}$ analyses [19].

\subsection{Bacterial Strains and Antimicrobial Testing}

Most of the tested strains were obtained from the American Type Culture Collection (ATCC): Staphylococcus aureus (ATCC 6538), Escherichia coli (ATCC 14948), Staphylococcus epidermidis (ATCC 12228), Streptococcus agalactiae (ATCC 12836), and Streptococcus dysgalactiae (ATCC 12388). 
Dra. Maria Aparecida Vasconcelos Paiva Brito from "Embrapa Gado de Leite" (Juiz de Fora-MG) kindly provided the isolated strains from clinical bovine mastitis cases. All strains were kept in our laboratory and cryopreserved at $-86{ }^{\circ} \mathrm{C}$. They were maintained in the brain-heart infusion (BHI) broth containing $20 \%(\mathrm{v} / \mathrm{v})$ glycerol. The minimal inhibitory concentration (MIC; lowest concentration of the compound able to inhibit microorganism growth) and the minimal bactericidal concentration (MBC; lowest concentration of the compound at which $99.99 \%$ or more of the initial inoculum was killed) were determined in triplicate, using the microdilution broth method in 96-well microplates. Samples were dissolved in dimethyl sulfoxide (DMSO; Synth, Diadema, SP, Brazil) at $1 \mathrm{mg} \mathrm{mL}^{-1}$ and diluted in tryptic soy broth (Difco, Sparks, MD, USA), which afforded concentrations ranging from 400.0 to $1.56 \mu \mathrm{g} \mathrm{mL}^{-1}$. The final DMSO content in the solutions was $5 \%(\mathrm{v} / \mathrm{v})$. A $5 \%(\mathrm{v} / \mathrm{v})$ DMSO solution was used as negative control. The inoculum was adjusted for each organism, to yield a cell concentration of $5 \times 10^{5}$ colony forming units (CFU) per $\mathrm{mL}$, according to previous standardization by the Clinical Laboratory Standards Institute [27]. One inoculated well was included, to control the adequacy of the broth for organism growth. One non-inoculated well, free of antimicrobial agent, was also employed, to ensure medium sterility. Penicillin was used as positive control. The only exception was E. coli, for which gentamicin was utilized as positive control. The microplates (96-wells) were sealed with plastic film and incubated at $37{ }^{\circ} \mathrm{C}$ for $24 \mathrm{~h}$. Then, an aqueous resazurin solution $(0.02 \%)$ was added to the microplates, to indicate microorganism viability. To determine $\mathrm{MBC}$ values, an aliquot of the inoculum was aseptically removed from each well with no apparent bacterial growth before addition of resazurin. The aliquot was then plated onto tryptic soy agar supplemented with 5\% sheep blood. The plates were incubated as previously described [27]. MBC values were only determined for the most active compound (CA).

\subsection{Kill Kinetics}

Time-kill assays were performed in triplicate based on D'Arrigo et al. [28]. Only CA against Staphylococcus aureus (ATCC 6538) was tested, because this compound displayed the highest antimicrobial activity. Tubes containing $\mathrm{CA}$ at final concentrations of $6.25,12.5$, and $18.7 \mu \mathrm{g} \mathrm{mL}^{-1}$ (respectively one, two, and three-times the MBC value of CA for S. aureus) were inoculated with the tested microorganism at a starting bacterial density of $5 \times 10^{5} \mathrm{CFU} \mathrm{mL}{ }^{-1}$ and incubated at $37{ }^{\circ} \mathrm{C}$. At 6 , 12 , and $24 \mathrm{~h}$ after incubation, samples were removed and diluted in sterile fresh medium, when necessary, for determination of viable strains. The diluted samples $(50 \mu \mathrm{L})$ were spread onto tryptic soy agar, incubated at $37^{\circ} \mathrm{C}$, and counted after $48 \mathrm{~h}$. Time-kill curves were constructed by plotting the $\log 10 \mathrm{CFU} \mathrm{mL} \mathrm{mL}^{-1}$ versus time. The assays were performed in triplicate for each concentration as well as the positive (penicillin at its $\mathrm{MBC}, \mathrm{PEN}, 0.046 \mu \mathrm{g} \mathrm{mL}^{-1}$ ) and negative controls (suspension of S. aureus without added CA).

\subsection{Cytotoxicity Assay}

The effect of CA on cell viability was assessed by the XTT assay using the primary human fibroblast cell line obtained from Coriell Cell Repositories (Camden, NJ, USA). Briefly, cells were trypsinized and seeded in 96-well plate at a concentration of $10^{4}$ cells/well in DMEM plus HAM-F10 $(1: 1, \mathrm{v} / \mathrm{v})$ medium (Sigma, St. Louis, MO, USA) supplemented with $20 \%$ fetal bovine serum (Life 
Technologies, CA, USA). After $24 \mathrm{~h}$ of incubation at $37{ }^{\circ} \mathrm{C}$, cell cultures were treated with different concentrations of CA dissolved in DMSO (1\%), namely from 7.8 to $62.5 \mathrm{uM}$, for further $24 \mathrm{~h}$. Cell viability was assessed with the Cell Proliferation Kit II (Roche, Mannheim, Germany) according to the manufacturer's instruction. Absorbance of the orange formazan product was detected at $490 \mathrm{~nm}$, reference wavelength at $620 \mathrm{~nm}$, in a microplate reader Sunrise (Tecam, Männdorf, Switzerland). Cell viability was expressed as the percentage of negative control. Doxorubicin at $3.0 \mu \mathrm{g} \mathrm{mL}^{-1}$ was used as positive control.

\section{Conclusions}

ent-Copalic acid is an important diterpene for the control of several Gram-positive bacteria related to bovine mastitis. The results reinforce the relevance of this class of natural products as a source of new potential antimicrobial compounds for the control of several human and animal infectious diseases.

\section{Acknowledgments}

The authors thank FAPESP (process no. 2011/13630-7), CNPq and CAPES for funds and grants.

\section{Conflict of Interest}

The authors declare no conflict of interest.

\section{References}

1. Hillerton, J.E.; Berry, E.A. Treating mastitis in the cow-A tradition or an archaism. J. Appl. Microbiol. 2005, 98, 1250-1255.

2. Baskaran, S.A.; Kazmer, G.W.; Hinckley, L.; Andrew, S.M.; Venkitanarayanan, K. Antibacterial effect of plant-derived antimicrobials on major bacterial mastitis pathogens in vitro. J. Dairy Sci. 2009, 92, 1423-1429.

3. Laport, M.S.; Marinho, P.R.; da Silva Santos, O.C.; de Almeida, P.; Villela Romanos, M.T.; Muricy, G.; Vasconcelos Paiva Brito, M.A.; Giambiagi-deMarval, M. Antimicrobial activity of marine sponges against coagulase-negative staphylococci isolated from bovine mastitis. Vet.Microbiol. 2012, 155, 362-368.

4. Newman, D.J. Natural products as leads to potential drugs: An old process or the new hope for drug discovery? J Med. Chem. 2008, 51, 2589-2599.

5. Almeida, L.S.B.; Murata, R.M.; Yatsuda, R.; Dos Santos, M.H.; Nagem, T.J.; Alencar, S.M.; Koo, H.; Rosalen, P.L. Antimicrobial activity of Rheedia brasiliensis and 7-epiclusianone against Streptococcus mutans. Phytomedicine 2008, 15, 886-891.

6. Kuzma, L.; Rozalski, M.; Walencka, E.; Rozalska, B.; Wysokinska, H. Antimicrobial activity of diterpenoids from hairy roots of Salvia sclarea L.: Salvipisone as a potential anti-biofilm agent active against antibiotic resistant Staphylococci. Phytomedicine 2007, 14, 31-35.

7. Porto, T.S.; Furtado, N.A.J.C.; Heleno, V.C.G.; Martins, C.H.G.; Da Costa, F.B.; Severiano, M.E.; Silva, A.N.; Veneziani, R.C.S.; Ambrosio, S.R. Antimicrobial ent-pimarane diterpenes from Viguiera arenaria against Gram-positive bacteria. Fitoterapia 2009, 80, 432-436. 
8. Porto, T.S.; Rangel, R.; Furtado, N.; De Carvalho, T.C.; Martins, C.H.G.; Veneziani, R.C.S.; Da Costa, F.B.; Vinholis, A.H.C.; Cunha, W.R.; Heleno, V.C.G.; et al. Pimarane-type diterpenes: antimicrobial activity against oral pathogens. Molecules 2009, 14, 191-199.

9. Habtemariam, S. In vitro antileishmanial effects of antibacterial diterpenes from two Ethiopian Premna species: P. schimperi and P. oligotricha. BMC Pharmacol. 2003, 3, 1-6.

10. Kalpoutzakis, E.; Chinou, I.; Mitaku, S.; Skaitsounis, A.L.; Hervala, C. Antibacterial labdane-type diterpenes from the resin "Ladano" of Cistus creticus Subsp. creticus. Nat. Prod. Lett. 1998, 11, 173-179.

11. Radulovic, N.; Denic, M.; Stojanovic-Radic, Z. Antimicrobial phenolic abietane diterpene from Lycopus europaeus L. (Lamiaceae). Bioorg Med. Chem. Lett. 2010, 20, 4988-4991.

12. Stavri, M.; Paton, A.; Skelton, B.W.; Gibbons, S. Antibacterial diterpenes from Plectranthus ernstii. J. Nat. Prod. 2009, 72, 1191-1194.

13. Wiart, C.; Au, T.S.; Mohd, Y.; Hamimah, H.; Sulaiman, M. 16 Alpha hydroxy-(-)-kauran-19-oic: An antibacterial diterpene from sweet apple (Annona squamosa L., Annonaceae). Int. J. Pharmacol. 2005, 1, 296-298.

14. Woldemichael, G.M.; Wächter, G.; Singh, M.P.; Maiese, W.M.; Timmermann, B.N. Antibacterial diterpenes from Calceolaria pinifolia. J. Nat. Prod. 2003, 66, 242-246.

15. Ambrosio, S.R.; Furtado, N.A.J.C.; De Oliveira, D.C.R.; Da Costa, F.B.; Martins, C.H.G.; De Carvalho, T.C.; Porto, T.S.; Veneziani, R.C.S. Antimicrobial activity of kaurane diterpenes against oral pathogens. Z. Naturforsch. C 2008, 63c, 326-330.

16. De Andrade, B.B.; Moreira, M.R.; Ambrosio, S.R.; Furtado, N.A.J.C.; Cunha, W.R.; Martins, C.H.G.; Veneziani, R.C.S. Evaluation of ent-kaurenoic acid derivatives for their anticariogenic activity. Nat. Prod. Commun. 2011, 6, 777-780.

17. Souza, A.B.; De Souza, M.G.M.; Moreira, M.A.; Moreira, M.R.; Furtado, N.A.J.C.; Martins, C.H.G.; Bastos, J.K.; Santos, R.A.; Heleno, V.C.G.; Ambrosio, S.R.; et al. Antimicrobial evaluation of diterpenes from Copaifera langsdorffii oleoresin against periodontal anaerobic bacteria. Molecules 2011, 16, 9611-9619.

18. Souza, A.B.; Martins, C.H.G.; Souza, M.G.M.; Furtado, N.A.J.C.; Heleno, V.C.G.; Sousa, J.P.B.; Rocha, E.M.P.; Bastos, J.K.; Cunha, W.R.; Veneziani, R.C.S.; et al. Antimicrobial activity of terpenoids from Copaifera langsdorffii Desf. against cariogenic bacteria. Phytother. Res. 2011, 25, 215-220.

19. Bastard, J.; Duc, D.K.; Fetizon, M.; Francis, M.J.; Grant, P.K.; Weavers, R.T.; Kaneko, C.; Baddeley, G.V.; Bernassau, J.M.; Burfitt, I.R.; et al. C-13 Nuclear Magnetic-Resonance Spectroscopy of Naturally-Occurring Substances .81. Cmr Spectroscopy of Labdanic Diterpenes and Related Substances. J. Nat. Prod. 1984, 47, 592-599.

20. Scheffran, R.H.; HSu, R.C.; Su, N.Y.; Huffman, J.B.; Midland, S.L.; Sims, J.J. Allelochemical resistence of Bald cypress Taxodium distichum, heartwood to the subterranean termite, Coptotermes formosanus. J. Chem. Ecol. 1988, 14, 765-776.

21. Do Nascimento, A.M.; De Oliveira, D.C.R. Kaurene Diterpenes and Other Chemical Constituents from Mikania stipulacea (M. Vahl) Willd. J. Brazil. Chem. Soc. 2001, 12, 552-555. 
22. Ohsaki, A.; Yan, L.T.; Ito, S.; Edatsugi, H.; Iwata, D.; Komoda, Y. The Isolation and in-Vivo Potent Antitumor-Activity of Clerodane Diterpenoid from the Oleoresin of the Brazilian Medicinal Plant, Copaifera langsdorfii Desfon. Bioorg. Med. Chem. 1994, 4, 2889-2892.

23. Gibbons, S. Phytochemicals for bacterial resistance-Strengths, weaknesses and opportunities. Planta. Med. 2008, 74, 594-602.

24. Rios, J.L.; Recio, M.C. Medicinal plants and antimicrobial activity. J. Ethnopharmacol 2005, 100, 80-84.

25. Gibbons, S. Anti-staphylococcal plant natural products. Nat. Prod. Rep. 2004, 21, 263-277.

26. Santana, H.F.; Barbosa, A.A.T.; Ferreira, S.O.; Mantovani, H.C. Bactericidal activity of ethanolic extracts of propolis against Staphylococcus aureus isolated from mastitic cows. World J. Microbiol. Biotechnol. 2012, 28, 485-491.

27. Clinical and Laboratory Standards Institute (CLSI). Methods for dilution antimicrobial susceptibility tests for bacteria that grow aerobically, In Approved Standard-Eighth Edition, CLSI Document M7-A8; CLSI: Wayne, PA, USA, 2009.

28. D'Arrigo, M.; Ginestra, G.; Mandalari, G.; Furneri, P.M.; Bisignano, G. Synergism and postantibiotic effect of tobramycin and Melaleuca alternifolia (tea tree) oil against Staphylococcus aureus and Escherichia coli. Phytomedicine 2010, 17, 317-322.

Sample Availability: Not available.

(C) 2013 by the authors; licensee MDPI, Basel, Switzerland. This article is an open access article distributed under the terms and conditions of the Creative Commons Attribution license (http://creativecommons.org/licenses/by/3.0/). 